\title{
Efficacy of Lyophilized Inactivated Rabies Vaccine
}

\author{
Omaima A. E. El-Shamandy ${ }^{1}$ and Heba M. G. Abd El-Aziz ${ }^{2 *}$ \\ ${ }^{1}$ Veterinary Serum and Vaccine Research Institute, Abassia, Agriculture Research Center (ARC), Egypt. \\ ${ }^{2}$ Central Laboratory for Evaluation of Veterinary Biologics, Abassia, Agriculture Research Center (ARC), Egypt. \\ "Corresponding Author, Heba M. G. Abd El-Aziz, E-mail: ahmhy20@ hotmail.com
}

\begin{abstract}
An interesting finding that emerged from the study was the difference in potency between inactivated rabies vaccines prepared in liquid and lyophilized forms. Inactivated rabies vaccine prepared from BHK21 infected cell culture in the two forms revealed that its immunogenicity was completely preserved on lyophilization. The two vaccine formulae were found to be free from foreign contaminants, safe in both inoculated mice and puppies and potent inducing high levels of specific rabies antibodies in vaccinated puppies. Such antibodies were increased gradually from the first-week post-vaccination to the same extent in the blood of immunized puppies with the lyophilized vaccine as in that of puppies immunized with liquid vaccine. These results confirmed the claim that inactivated rabies vaccines could be lyophilized with retention of potency. Considering the possible value of a stable, freeze-dried rabies vaccine that could be stored and transported with ease, it was considered desirable to confirm the above findings.
\end{abstract}

Keywords: Immunoglobulins, lyophilization, Rabies, Vaccine.

\author{
Original Article: \\ DOI: \\ https://dx.doi.org/10.21608/javs.2020.1 \\ 20348
}

Received : 19 Sept., 2020.

Accepted :21Oct., 2020.

Published in October, 2020.

This is an open access article under the term of the Creative Commons Attribution 4.0 (CCBY) International License . To view a copy of this license, visit:

http://creativecommons.org/licenses/by/4.0/

\section{INTRODUCTION}

Rabies disease is an acute progressive, fatal encephalomyelitis caused by neurotropic RNA viruses in Rhabdoviridae, genus Lyssavirus. (Rupporecht $\boldsymbol{e t}$ al., 2010). Rabies or Hydrophobia is affecting wild, domestic animals and humans. The popular wide, case fatality rate is high, is almost $100 \%$. Rabies is a lifethreatening disease that is usually transmitted to human and animals through bites from rabid animals; scratch wounds or licking of the mucous (Nigg and Walker, 2009). Regarding Egypt, rabies is enzootic in jackals and common in dogs (El-Kanawati et al., 2000). Active immunization of susceptible hosts using potent vaccines is the cornerstone of rabies control. Inactivated cell culture rabies vaccines were provided by many authors (Larghi and Nebel, 1980; Edries, 1994 and Khodier, 1999).

The rabies vaccine generally adopts administered subcutaneously, conventionally has an aqueous section. The lyophilizing parameter has an obvious impact on the character of the rabies vaccine. The contents of the lyophilized rabies vaccine have a protective effect on its heat stability. Meanwhile, the selection of the freeze-dry process route and lyophilizing parameter also has an obvious impact on vaccine character. Various preparations of lyophilized and liquid inactivated antirabies vaccines were assessed for antigenicity related to the NIH (United States National Institutes of Health) Reference Vaccine 164 (the proposed International Reference Preparation of Rabies Vaccine). The claim that inactivated antirabies vaccines can be lyophilized without loss of antigenicity was fully substantiated: the lyophilized vaccines were found to possess high antigenic values and to retain their antigenicity better than the liquid vaccines during storage under the same conditions (Veeraraghavan, and Subrahmanyan, 1961).

The present invention was designed to evaluate the effect of lyophilization; as a method of veterinary rabies vaccine in a form that may elongate its shelf life, on its antigenicity and accordingly on its immunogenicity.

\section{MATERIALS AND METHODS}

\section{Ethical approval}

Care and use of laboratory animals were approved by the Medical and Veterinary Research Ethics Committee at the National Research Centre in Egypt. 


\section{Animals}

1.1.Mice

Thirty-two Swiss Albino weaned mice were supplied by the Laboratory Animal Breeding Unit (LABU) at Veterinary Serum and Vaccine Research Institute (VSVRI). They were used to study the prepared rabies vaccine formulae's safety divided into four groups (8 mice/ group).

\subsection{Puppies}

Twenty native breed healthy puppies of about 3-4 months age were found to be free from rabies antibodies as screened by serum neutralization test (SNT) and free from external and internal parasites were used to evaluate the safety and potency of prepared rabies lyophilized inactivated vaccine formulae in comparison with that of the locally produced liquid inactivated vaccine.

\section{Virus}

BHK-21 cell culture adapted Evelyn Rokintniki Abelseth (ERA) strain of rabies virus with a titter $10^{7} \mathrm{TCID}_{50} / \mathrm{ml}$ (Edries, 1994); was supplied by the Department of Pet Animal Vaccine Research (DPAVR), (VSVRI) Abassia Cairo and used in vaccine preparations and serum neutralization test.

\section{Cell culture}

Baby hamster kidney cell line $\left(\mathrm{BHK}_{13}\right)$; was supplied by VSVRI and used in the propagation of rabies virus for vaccine preparations and serum neutralization test.

\section{Virus titration}

BHK-21; cell lines were used to titrate rabies where serial ten-fold dilutions of the virus were prepared in Hank's balanced salt solution $\left(10^{-1}\right.$ to $10^{-10}$ dilutions). Twenty-five microliters of each dilution were inoculated in each of 5 wells in a 96-well tissue culture plate containing a confluent cell sheet. The plates were incubated at $37^{\circ} \mathrm{C}$ for one hour with intermittent tilting. After adsorption, the maintenance medium was added. The plates were examined daily for 5days to detect the CPE. The virus titer was expressed as $\log _{10} \mathrm{TCID}_{50} / \mathrm{ml}$ of the original inoculums using the formula of Reed and Meunch (1938).

\section{Binary Ethyleneimine working solution $0.1 \mathrm{M}$}

It was prepared according to Girard et al. (1977), were $2.05 \mathrm{gm}$ of 2-bromoethlamine hydrobromide (Aldrich Chemical LTD Company) was dissolved in $100 \mathrm{ml}$ of $0.2 \mathrm{Mol}$ sodium hydroxide solution $(800 \mathrm{mg} \mathrm{NaOH})$ in $100 \mathrm{ml}$ distilled water. The content was incubated in a water bath at $37^{\circ} \mathrm{C}$ for one hour, followed by filtration through Millipore filter. The solution was immediately used as a virus inactivator. $20 \%$ solution of sodium thiosulphate-5 hydrate was prepared in distilled water and used to stop the action of the BEI inactivated virus fluid

\section{Virus inactivation}

The inactivation process was carried using $3 \%$ of the stock Binary Ethyleneimine (BEI) solution at $37^{\circ} \mathrm{C}$ for 3.5 hours for rabies virus according to Edries (1994).

\section{Preparation of liquid inactivated rabies vaccine}

A portion of the inactivated rabies virus was mixed with Monatide pet gel A was added at the ratio of $10 \%$ as adjuvant according to the manufacturer directions (Edries et al., 2017).

\section{Preparation of lyophilized inactivated rabies vaccine}

A stabilizer ( $5 \%$ lactalbumin hydrolysate and $2.5 \%$ sucrose) was added to a portion of the inactivated rabies virus in the ratio of $1: 1$, then dispensed in neutral, sterile vials $(1.5 \mathrm{ml} / \mathrm{vial})$ and subjected to freeze-drying (lyophilization) process according to Attyat (1994). In addition, another portion of the prepared gel vaccine was subjected to the lyophilization process without adding a stabilizer.

\section{Freeze-drying process}

The lyophilizing technique was carried out on the Tofflon lyophilizer apparatus according to Wang and Zhang, 2007; Zhou et al., 2007 and Shao-Zhi et al., 2010) then kept at $-20^{\circ} \mathrm{C}$ till subjected for evaluation of the effect of the lyophilization process on the vaccine potency.

\section{Quality control testing of the prepared vaccines: 10.1. Sterility test}

Sterility testing of the prepared vaccine formulae was carried out according to tFAO'sstandard procedures o1994), OIE (2018) using thioglycolate, soybean casein digest; sabouraud; mycoplasma solid and liquid media.

\subsection{Safety test}

\subsubsection{In mice}

Thirty-two mice were divided into four groups (8mice/group). The first group was used for the liquid vaccine formula; the second for the stabilizer lyophilized vaccine formula; the third for the gel lyophilized vaccine formula, while the fourth group was kept as a test control. According to the British Pharmacopeia (1985), each vaccine was inoculated intraperitoneally in each of 8 weaned Swiss Albino mice. All mice were kept under observation for 10 days.

\subsubsection{In puppies}

Six puppies were divided into three groups (2puppies/group) to test the three prepared inactivated rabies vaccine formulae's safety. Each group was inoculated S/C with 10 doses of each vaccine formula and kept under daily clinical observation for 10 days according to Amani et al. (2002) and Zeinab et al. (2003). 


\subsection{Potency}

Fourteen puppies were divided into four groups (4puppies/each of the first three groups) where the first group was vaccinated with the lyophilized stabilizer vaccine formula after its reconstitution in $1 \mathrm{ml}$ normal saline; the second group was vaccinated with the lyophilized gel vaccine formula after its reconstitution in $1 \mathrm{ml}$ normal saline and the third group was vaccinated with $1 \mathrm{ml}$ of the liquid vaccine formula according to Edries et al. (2017) and the fourth group (2 puppies) was kept without vaccination as control.

\section{Serum neutralization test (SNT)}

SNT was carried out to estimate rabies neutralizing antibodies in the serum of vaccinated animals, as described by Yoneda et al. (2008). The antibody titer was determined as the reciprocal of the final serum dilution which neutralized and inhibited the appearance of the cytopathic effect (CPE) of 100 TCID50 of rabies virus according to Singh et al. (1967).

\section{Rabies virus antibody quantitates ELISA kit:}

Zhenrui Rabies virus antibody quantitate ELISA kit, version RBV1805003 was supplied by Shenzhen Zhenrui Biotech Co., Ltd; Add 7Floor, Gaoke Building, Yueliangwan Road, Nanshan District, Shenzhen, China where rabies antibody titer was expressed as IU/ml according to the standard curve performed by the kit manufacturer.

\section{RESULTS}

Table 1: Mean rabies serum neutralizing antibody titers in vaccinated puppies

\begin{tabular}{|c|c|c|c|c|}
\hline $\begin{array}{c}\text { Periods } \\
\text { of } \\
\text { post-vaccination }\end{array}$ & \multicolumn{4}{|c|}{$\begin{array}{c}\text { Mean rabies serum neutralizing } \\
\text { antibody titer* in puppies }\end{array}$} \\
\cline { 2 - 5 } & $\begin{array}{c}\text { Group } \\
1\end{array}$ & $\begin{array}{c}\text { Group } \\
2\end{array}$ & $\begin{array}{c}\text { Group } \\
3\end{array}$ & $\begin{array}{c}\text { Group } \\
4\end{array}$ \\
\hline Pre-vaccination & 0 & 0 & 0 & 0 \\
\hline $1 \mathrm{WPV} * *$ & 2 & 4 & 4 & 0 \\
\hline $2 \mathrm{WPV}$ & 8 & 8 & 8 & 0 \\
\hline $3 \mathrm{WPV}$ & 16 & 16 & 32 & 0 \\
\hline $4 \mathrm{WPV}$ & 64 & 64 & 64 & 0 \\
\hline $2 \mathrm{MPV} * * *$ & 128 & 128 & 128 & 0 \\
\hline $4-6 \mathrm{MPV}$ & 128 & 128 & 128 & 0 \\
\hline
\end{tabular}

* Mean rabies serum neutralizing antibody

$* * \mathrm{WPV}=$ week post-vaccination

$* * * \mathrm{MPV}=$ month post-vaccination.

Group-1: vaccinated with the lyophilized stabilizer vaccine formula after its reconstitution in $1 \mathrm{ml}$ saline Group-2: vaccinated with the lyophilized gel vaccine formula reconstituted in $1 \mathrm{ml}$ normal saline

Group-3: vaccinated with $1 \mathrm{ml}$ of the liquid vaccine formula Group-4: inoculated with normal saline and kept without vaccination as a control
Table 2: Mean rabies ELISA values in vaccinated puppies

\begin{tabular}{|c|c|c|c|c|}
\hline \multirow{2}{*}{$\begin{array}{c}\text { Periods post- } \\
\text { vaccination }\end{array}$} & \multicolumn{4}{|c|}{$\begin{array}{c}\text { Mean rabies ELISA values in } \\
\text { puppies }\end{array}$} \\
\cline { 2 - 5 } & $\begin{array}{c}\text { Group } \\
1\end{array}$ & $\begin{array}{c}\text { Group } \\
2\end{array}$ & $\begin{array}{c}\text { Group } \\
3\end{array}$ & $\begin{array}{c}\text { Group } \\
4\end{array}$ \\
\hline Pre-vaccination & 0.1 & 0.0 & 0.05 & 0.01 \\
\hline 1WPV* & 0.3 & 0.3 & 0.4 & 0.0 \\
\hline 2WPV & 1.0 & 1.1 & 1.1 & 0.0 \\
\hline 3WPV & 1.5 & 1.8 & 1.7 & 0.02 \\
\hline 4WPV & 2.0 & 2.1 & 2.04 & 0.0 \\
\hline 2MPV** & 2.1 & 2.11 & 2.1 & 0.0 \\
\hline 4-6MPV & 2.11 & 2.2 & 2.2 & 0.0 \\
\hline
\end{tabular}

*WPV= week post-vaccination . $* * \mathrm{MPV}=$ month post-vaccination.

ELIZA results were expressed as $\mathrm{IU} / \mathrm{ml}$ where the protective value should not be less than $0.5 \mathrm{IU} / \mathrm{ml}$ representing a protection value of $58.4 \%$.

Group-1: vaccinated with the lyophilized stabilizer vaccine formula after its reconstitution in $1 \mathrm{ml}$ normal saline.

Group-2: vaccinated with the lyophilized gel vaccine formula reconstituted in $1 \mathrm{ml}$ normal saline.

Group-3: vaccinated with $1 \mathrm{ml}$ of the liquid vaccine formula.

\section{DISCUSSION}

Rabies is a viral disease caused by nonsegmented -ve strand RNA virus that belongs to the genus lyssavirus, family Rhabdovirde. Rabies mainly transmitted through a bite of a rabid animal, infecting the central nervous system of mammals and human causing disease in the brain leading to death (Deborah et al., 2013). Vaccination against rabies is the most important step to face such a disease. Several studies showed that the inactivated rabies vaccine of tissue culture origin induced high antibody response (Charles et al., 2013). There is always a need to make a new modification in the vaccine preparation to achieve high safety and potency. WHO (2018).

In this study, we prepared three vaccine formulae to determine which vaccine formula will give the highest efficacy. The first one is the lyophilized stabilizer vaccine, $2^{\text {nd }}$ one lyophilized gel vaccine and the $3^{\text {rd }}$ one liquid vaccine. Rabies vaccine lyophilized formulations, before preparation, need to add a stabilizing agent, protective agent and excipient. The stabilizer additive component and have a protective effect on the heat stability of the rabies vaccine. Meanwhile, the selection of the freeze-dry process route and lyophilizing parameter also has an obvious impact on vaccine character. 
The preparation method that the object of this invention is to provide a kind of lyophilized formulations of rabies vaccine; the present invention is by being optimized combination of the stabilizing agent of vaccine liquid and protective agent; improve freeze-dry process route and parameter when making shelf-life of lyophilizing rabies vaccine longer, vaccine valence meets the national standard.

Rabies vaccine lyophilized formulations product and the liquid form are tested. All formulae were found to be free from aerobic and anaerobic bacteria, fungi, and mycoplasma and did not induce any abnormal local or systemic post inoculation reactions in mice and puppies. All animals remain in good health. These findings came in agreement with the recommendation of WHO (1973) and it will be seen from the data presented that all the prepared inactivated rabies vaccine formulae tested passed the potency requirements and retained their immunogenic properties.

Tables (1 and 2) demonstrated that all tested rabies vaccine formulae induced detectable serum neutralizing and ELISA rabies antibodies in vaccinated puppies by the first-week post-vaccination recorded their mean peak titer the $2^{\text {nd }}$ month post-vaccination to be 128 by SNT and 2.1-2.2IU by ELISA. These values indicated that all prepared rabies vaccine formulae are safe and potent for puppies in agreement with Bass $\boldsymbol{e t}$ al. (1982); Khodeir (1999); Khodeir and Daoud (2008); Albehwar (2009); Eiaka (2017) and Edreis et al. (2017) using cell culture inactivated rabies vaccine adjuvanted with aluminum hydroxide gel and recommended that the protective level of rabies serum neutralizing antibodies should not be less than 8 and $0.5 \mathrm{IU}$ by ELISA. These results also agree with (Charles et al ., 2013).

These results indicated that the lyophilization process did not affect the immunogenicity of rabies virus using stabilizer or pet gel as additives coming in complete agreement with Veeraraghavan and Subrahmanyan (1961), who showed that inactivated antirabies vaccines could be lyophilized without loss of antigenicity and the lyophilized vaccines were found to possess high antigenic values and retain their immunogenicity better than the liquid vaccines during storage.

\section{CONCLUSIONS}

Depending on the obtained results and collected data, it could be said that lyophilized inactivated rabies vaccine can be provided as a safe, potent vaccine suggesting that it has a long shelf life. There is a need to study the stability of the dried product over a long time.

\section{Declaration of Competing interest}

On behalf of all authors, I hereby declare that no conflict of interest may interfere with the publication of the manuscript.

\section{REFERENCES}

AL-BEHWAR, A.M., 2009. Studies on prophylactic and emergency vaccination of farm animals against rabies, Ph. D. Thesis (Infectious diseases) Fac. Vet. Med. Cairo Univ.

AMANI, A. SALEH; EL-GALLAD, S.B.; KHODEIR, M.H. AND AZAB, A.M., 2002. Trivalent inactivated vaccine for dogs (Rabies, Canine Distemper and Canine Parvo), J. Egypt Vet. Med. Ass. 62, No.2: 209-222.

ATTYAT M. KOTB, 1994. Studies on preparation of canine parvo vaccine, $\mathrm{Ph}$. D. Thesis (Microbiology) Fac. Vet. Med. Cairo Univ.

BASS, E.P.; GILL, M.A., AND BECKENHAUR, W.H., 1982. Development of a modified live canine origin parvovirus vaccine JAVMA, 181 (9): 909-913.

CHARLES. E.RUPPRECHT, STANLY.A.PLOTKIN 2013. Scientific Basis of the Disease and Its Management. Elsevier, Science Direct, sixth edition 2013.

DEBORAH J.BRIGGS, THIRUMENI NAGARAJAN, CHARLES E.RUPPRECHT, 2013. Scientific Basis of the Disease and Its Management. Elsevier, Science Direct, third edition chapter13, 2013.

EDRIES, S. M., 1994. Production of inactivated tissue culture rabies vaccine, Ph. D. Thesis, Fac. Vet. Med. Virology, Cairo Univ

EDRIES, S.M.; AMANI, A. SALEH; ALBEHWAR, A.M. AND HEMMET, S. E. EL-SHAMY,2017. Improvement of inactivated rabies vaccine using montanid pet gel-a Benha J. Applied Sci. (BJAS) Vol (2) Issue (1) Oct. (2017), 145-149

EIAKA, A.M.E., 2017. Virological and immunological studies on the effect of bee venom on rabies virus, $\mathrm{Ph}$. D. Thesis (Virology) Fac. Vet. Med. Benha Univ.

EL-KANAWATI, Z. R.; IKRAM, A. KARIM; AFAF, AMIN; AND EL-EBEEDY, A. A., 2000. Occurrence of rabies in Egypt during 1997-1999, J. Egyp. Vet. Med. Ass., 60: 47-54.

FAO., 1994. Quality control of rinderpest cell culture vaccine, Standard Operating Procedures, FAO report No. 118

GIRARD, H.C.; BAYRAMOGLU, O.; EROL., N. AND BURGUT, A., 1977. Inactivation of (O1) FMD virus by binary ethylenimine (BEI), Bull. Off. Int. Epiz. 87(3-4): 201-217.

KHODIER, M. H., 1999. Studies on vaccination of farm animals (cattle, horse, sheep) in addition to dogs and cats with inactivated tissue culture rabies vaccine, Beni-Suif Vet. Med. J.;9 (3-A): 111-120.

KHODEIR, M. H. AND DAOUD, A. M., 2008. Preparation of antirabies hyperimmune serum for emergency Immunization of farm animals. $4^{\text {th }}$ Int. Sci. Conf. NRC, 1-9.

LARGHI, O.P. AND NEBEL, A.E., 1980. Rabies virus inactivation by Binary Ethyleneimine: New method 


\section{Efficacy of Lyophilized Inactivated Rabies Vaccine}

for inactivated vaccine production, J.Clic.Microbiol.2: 120-122

NIGG, A. J. AND WALKER, P. L., 2009. Overview: prevention and treatment of rabies, Pharmacotherapy 2009 Oct.; 29 (10): 1182-1185.

REED, L.J. AND MUENCH, H., 1938. A simple method for estimating fifty percent $(50 \%)$ endpoints, Amer. J. Hyg., 27: 493-497.

RUPPORECHT, C. E.; BRIGGS, D. AND BROWN, C. M., 2010. Use of a reduced (4 doses) vaccine schedule for post-exposure Prophylaxis to prevent human rabies recommendations of the Advisory Committee on immunization practices. MMWR Recomm. Rep. 59:1-9.

SHAO-ZHI, Z.; HUAN, Q.; ZHEN, W.; JU-LI, F.; QIAN, Z.; GUANG-MING, C.; RUI, L.; SHAN, F. AND JIE, S., 2010. Preliminary study on the freezedrying of human bone marrow-derived mesenchymal stem cells, J. Zhejiang Univ. Sci. Bv., 11 (11).

SINGH, K.V.; OSMAN, O.A.; THANAA, I.BAZ AND IVON, EL-CICY, 1967. Colostral transfer of rinderpest neutralizing antibodies offspring of vaccinated dams, Can. J. Comp. Med. Vet. Sci., 31: 295-298.

VEERARAGHAVAN, N. AND SUBRAHMANYAN, T.P., 1961. Antigenic Value of Lyophilized Phenolized Antirabies Vaccine, Bull. Org. Mond. Santg Bull. Wid Hlth.Org.1961, 25, 115-117.

WANG, J. AND ZHANG, H., 2007. The influence of onestep $-80{ }^{\circ} \mathrm{C}$ cryopreservation on the osteogenesis differentiation ability of human bone marrow-derived mesenchymal stem cells, Guangdong Med., 28(3):365-367.

WHO 1973. Expert committee on biological standardization; requirements of rabies vaccine for human use, Tech. Rep. Ser., 658: 54-130.

WHO (2018): Rabies vaccines and immunoglobulins, WHO position in April 2018.

YONEDA, A.; TUCHIYA, K.; TAKASHIMA, Y.; ARAKAWA, T.; TSUJI, N.; HAYASHI, Y. AND MATSUMOTO, Y., 2008. Protection of mice from rabies by intranasal immunization with the inactivated rabies virus. Exp. Anim., 57 (1): 1-9.

ZEINAB, T. S. SALAMA; NAGLAA, I. ALI; GUIRGUIS, W.I. AND KHODEIR, M.H., 2003. Modification of the inactivated trivalent vaccine (Rabies; canine distemper and canine parvo) used for dogs to improve its immunogenicity, J. Egypt Vet. Med. Ass. 63, No.2: 137-146.

ZHOU, X.L.; ZHU, H.; ZHANG, S.Z.; ZHU, F.M.; CHEN, G.M. AND YAN, L.X., 2007. Freeze-drying of human platelets: influence of saccharide, freezing rate and cell concentration, Cryo Letters., 28(3):187196.
How to cite this article:

Omaima A. E. El-Shamandy ${ }^{1}$ and Heba M. G. Abd El-Aziz' 2020. Efficacy Of Lyophilized Inactivated Rabies Vaccine.Journal of Applied Veterinary Sciences, 5(4): 68 - 72.

DOI: 10.21608/JAVS.2020.120348 